\title{
The Phonological Interference in EFL Reading
}

\author{
Made Wahyu Mahendra \& I Made Yogi Marantika \\ Universitas Mahasaraswati, Denpasar, Indonesia \\ (wahyumahendraedu@gmail.com)
}

\begin{abstract}
The study aimed at exploring the phonological interference made by Pendalungan students in EFL reading, particularly in vowel phonemes. Pendalungan is an assimilation of two majority ethnics in Eastern Java; Java and Madura. Due to the unique characteristics of the language used by this group of community, it is assumed that the errors made by EFL Pendhalungan students might show different patterns as those found in either Javanese and Madurese students. To answer the problem of the research, the descriptive qualitative design was employed. There were eight students who belonged to the Pendalungan community, from a private university in East Java were taken as respondents. The secondary instruments used was an oral test of reading an English text. The finding showed that there were 12 incorrecty pronounced vowels; /I, av,

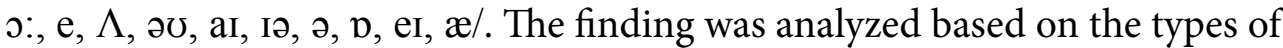
phonological interference, namely sound addition, sound omission, and sound replacement. The first two types have the least cases of two for each, while the last type has the most. Furthermore,the phonological interference emerged in the finding is somehow related to the nature of both languages, Javanese and Madurese. Inaccuracy mostly occurs because students pronounce the words as they are written.
\end{abstract}

Keywords: Pendalungan; L1 interference; reading error; audio recordings.

It is well understood that first language (L1) may affect second language (L2) acquisition in one way or another. The case of English learned as a second language in Indonesia is quite complicated due to the fact that most of Indonesian learners are bilinguals in Indonesia and their local languages. Some studies on phonology conducted in Indonesia have found different potential difficulties in
EFL production experienced by learners with different L1s (Muhassin, 2018; Wardani \& Suwartono, 2019; Aulia, 2018; Ambalegin \& Hulu, 2019; and Suryani, 2018). These studies mainly suggest that phonological interferences of the EFL students come from the nature of their language, some also posit that these interferences are results of limited exposure to the target language. Nevertheless, these studies 
make a room for more explorative research on phonology interference in Indonesian's EFL students.

The island of Java as one of the largest islands in Indonesia is home for 10 vernaculars (Harwan, 2019). In Eastern Java, Madurese and Javanese are two among mostly spoken local languages. These languages have somehow assimilated and resulted in a unique form of language, spoken by a community identified as Pendalungan. The members of the community are mostly bilinguals, therefore some features of the two languages overlap. The majority of Pendalungan people can be found particularly in Jember. For people whose first language is Javanese or Madurese might think that the language spoken by Pendalungan people sound unfamiliar. It is because they tend to mix the two languages lexically, grammatically, or phonologically, making it unique. However, as this is a product of assimilation, researchers hardly say that it is a new form of culture or language.

In the book of Orang Pendalungan (Pendalungan People) (Zoebazary, 2017), it has been elaborated that this assimilation is still shaping its identity as a culture. It is said to take form as an urban culture where the people tend to accept any different culture to adapt in the new environment. Zoebazary also mentioned that due to the absence of strong traditional basis of Pendalungan, its people are commonly oriented to contemporary cultural values (which supports the idea of the urban culture). Speaking of its language, although Pendalungan people commonly are bilingual in Javanese and Madurese, their Javanese is usually dominant; resulting in Pendalungan's dialect of Javanese (Raharjo, 2006). By Pendalungan's dialect of Javanese means that they speak Javanese but oftentimes use Madurese accent. Sometimes, they mix words of Madurese with Javanese. Therefore, a 'true' Javanese person would find it hard to decide whether they speak Javanese or Madurese due to their differing accent. This, somehow, creates a language identity of Pendalungan.

The nature of Pendalungan as a language attracts the author to research more on its phonological aspect. As related to the second language acquisition where the learner's L1 usually interferes, it is worth an assumption that EFL students who belong to Pendalungan people might find difficulties in producing phonemes as found interfering in both the Madurese's and Javanese's EFL learners. Some previous studies on the phonological interference in Madurese EFL learners found that these students added, omitted, and replaced a number of sounds, such as [ə], [I], [r], [1] (Muhassin, et al., 2018). While the most current study on the phonological interference of Javanese EFL learners indicated problems in producing the sounds of " 13 consonants $/ 3, \mathrm{v}, \theta, \mathrm{\partial}, \mathrm{z}, \int, \mathrm{f}, \mathrm{g}$, $\mathrm{k}, \mathrm{d}, \mathfrak{t}, \mathrm{\eta}, \mathrm{j} /$ and 17 vowel sounds /æ, $\varepsilon$, $\mathrm{i}$ :, eI,

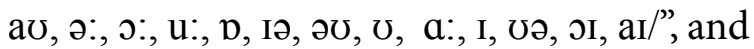
substituted the diphthongs into short vowels, or monophthongized (Wardani \& Suwartono, 2019. The study assumed that the problems occur due to the absence of diphthongs in Javanese language, thus make them pronounce the diphthongs as short vowels (those similar with ones in their mother tongue) or simply read the words as written (orthography). However, as previously described although Pendalungan people are bilinguals, Javanese language is mostly dominant. Following these findings, the present study assumed that the phonological interference of Pendalungan people as EFL learners might resemble that of the Javanese students.

Interference in the theory of SLA is often regarded as a certain process, because it is a natural process of acquiring a new language. A famous term by Ellis (1997) says that interference is a 'transfer'. It is a process of transferring features of L1 which are transferrable while acquiring L2. Learners will spot differences and similarities between the L1 and L2. The similar features between the two languages will result in a better perception of the language. On the other hand, the 
differences may cause problem in acquiring the language. Wells (2000) points out that interference, when observed objectively, is a cognitive attempt made by a L2 student when pronouncing an unfamiliar sound of L2 using a sound that is familiar to them (L1) aiming to sound understandable.

A well-known division of interference was introduced by Weinreich (1953), namely the lexical, grammatical, and phonological interference. Phonological interference, as one of the types, is the most observable one because it is productive by nature. One well-known theory on this is perception-production link. Flege (1995) proposed Speech Learning Model (SLM). In his conclusion, only the different feature of the language will remain as a new L2 category in learners' perception. When L2 category is different and the production is accurate means that the learner has perceived a new phonetic category accurately. Therefore, it is important to predict whether the learners' L1 might interfere their L2 acquisition in order to allow better acquisition of the target language.

Phonological interference may take form in approximately three categories of interference as suggested by Crystal (2003). These categories are sound addition, sound omission, and sound replacement. The first category occurs when L2 learner adds another sound or phoneme to the supposed phonetic. What is common in Indonesian learners are adding the phoneme $/ \mathrm{k} /$ when pronouncing the word 'know'. So, instead of saying /nəo/, learners say $/ \mathrm{kn} ə 0 /$. This phenomenon might be caused by the lack of exposures to the target language and lack of understanding of the target language's phonological rules (Wardani \& Suwartono, 2019). Moreover, Indonesian words are mostly pronounced as they are written, therefore it is not easy to adapt to the new feature of phonology in the target language. The second category is sound omission. In this category, L2 learner tends to omit phonemes where they are supposed to be pronounced. It usually occurs in pronunciation of diphtongs which are simplified to short vowels, such as out /avt/ pronounced as /pt/ or home $/$ həom/ pronounced as $/ \mathrm{hpm} /$. Finally, the last category of phonological interference is sound replacement. This category is identified by replacing the standard phoneme with another phoneme. The replacement is like in phoneme /æ/ in word dad/dæd/ replaced by /e/ so /ded/ or like in dead.

Referring to studies on Madurese and Javanese students' phonological interferences, it is known that problem of pronouncing vowels (including short vowel, long vowel, and diphthongs) occurred quite frequently. In addition, the nature of Pendalungan language which is an assimilation of Madurese and Javanese, it is intriguing to explore whether the problems of both languages as found in studies occur simultaneously or the Javanese problems occur more dominantly, bearing in mind that the Javanese is more dominant in Pendalungan. In addition, as phonological interference, as other kinds of interference, can be traced back to the mother tongue to analyze where the errors come from. The errors might occur due to developmental errors, interlingual errors, ambiguous errors, and other errors (Dulay et al., 1982). Therefore, the present study aimed at exploring in-depth phonological interference of Pendalungan language on English as a foreign language at students of English department of a private university in East Java, Indonesia, particularly in English standard vowels.

\section{Method}

This study is descriptive qualitative, as its focus is to explore in-depth phonological interference of Pendalungan language on English as a foreign language at 8 students of English department in a private university in East Java, Indonesia. The students as sources of the research data were selected using the purposive sampling, meaning that they were selected due to two main criteria, namely a) have taken Basic Pronunciation class and b) bilingual in Javanese and Madurese languages. 
All the subjects have taken Basic Pronunciation in their first year. The researchers also have checked their bilingualism. Some of them were children of Javanese parents but lived in Madurese speaking environment, while some others were the other way around or they were Madurese but as they moved in the town for their higher education (they lived in suburbs of Jember), they acquired the language through interactions with their Javanese friends and could communicate in both languages fluently. These criteria were considered important in order to obtain reliable data for the descriptive study.

The data was in the form of audio recordings of the students' reading an English text. The text contained 19 vowels, missing one vowel of /vo/, as referring to the standard International Phonetic Alphabets (IPA). The audio-recording process was done by every subject remotely, and on a later date they submitted to the researcher. Therefore, it is assumed that they had been given enough time to prepare themselves before reading, not an impromptu reading, allowing more reliable data of students' pronunciation skill. The audio recordings were clear and in a good quality, allowing better listening. Phonetic analysis was done by the researchers to see at which vowels they made errors. Upon doing this stage, the researchers categorized the errors following the phonological interference categories and summarized it in a form of pattern. The pattern as finding was expected to give better description of the phonological interference of Pendalungan language in English as the foreign language.

\section{Results and Discussion}

The present study explored how students perceived the English phonetic from through reading. Table 1 presents the result of analysis of the audio recordings. Errors made by only 1 student each are not displayed because of the possibility of their not showing patterns. As seen in the table, most errors occur when student pronounce the words experience
/Ik'spirıəns/, around /a'raond/, saw /'so:/, and counterterrorism /,kauntə'terərızəm/, and the least frequent errors are suspected, police, containing, components, houses, squad, black, bag, among, others, headquarters, and explosive. In total, 12 vowel phonemes were pronounced incorrectly by the subjects, such as /I, a , ə:, e, $\Lambda$, əひ, aI, Iə, ə, p, eI, æ/. However, the subjects were not entirely unaware of these phonemes; when these phonemes are in different words, the subjects pronounced them correctly, but pronounced them incorrectly in others. For instance, the vowel /æ/ is correct in hanging but incorrect in black and bag, or the word nails were pronounced correctly with /ei/ but in the word cable, 3 students got it incorrect. The findings are in line with both studies of Wardani \& Suwartono (2019) and Muhassin et al. (2018). The former have identified /æ, عə, i:, eI, a , ə:, ə:, u:, p, əə, əひ, $\mho, a:, \mathrm{I}$,, , गI, aI/ as inaccurately pronounced vowels of Javanese students, while the latter mentioned $/ \mathrm{a} /$ and $/ \mathrm{I} /$ as the problems.

The same vowel phonemes were found to occur in multiple frequency categories. For example, /av/ is wrongly pronounced by 7 students, 3 students, and 2 students, while $/ \mathrm{I} /$ is wrongly pronounced by 8 students, 6 students, 3 students, and 2 students. The words represented by each error is different, as in phoneme $/ \mathrm{I} /$, at least three words are represented for its error, such as the word experience, eradication, and explosives. All the three words are initiated with the letter 'e', which according to Indonesian alphabet, it is pronounced as /e/. Surprisingly, these three words, instead of pronounced with /I/, were pronounced with /e/.

\section{Phonological Interference of Pendalungan Language}

The findings presented in the table and above description have given a fundamental material for us to discuss the emerging patterns. These patterns will be discussed in each type of phonological interference (sound addition, omission, and replacement). 
Table 1. List of Errors in Vowel Phonemes

\begin{tabular}{|c|c|c|c|c|}
\hline No. & $\begin{array}{l}\text { Frequency of } \\
\text { Errors }\end{array}$ & Vowels & in words & $\begin{array}{l}\text { Pronounced (in pho- } \\
\text { nemes) }\end{array}$ \\
\hline 1 & 8 students & I & experience & $\mathrm{e}$ \\
\hline \multirow[t]{2}{*}{2} & 7 students & av & around; counterterrorism & $\circlearrowleft \mho($ not in IPA) \\
\hline & & 0: & saw & av \\
\hline \multirow[t]{2}{*}{3} & 6 students & e & said & eI \\
\hline & & I & experience & $\mathrm{e}$ \\
\hline 4 & 5 students & & & \\
\hline \multirow[t]{4}{*}{5} & 4 students & $\Lambda$ & corruption & $\mho$ \\
\hline & & $\partial \mho$ & home & ๗(not in IPA) \\
\hline & & aI & pipe; comprising; assigned & I \\
\hline & & Iə & experience; material & Ie (not in IPA); e \\
\hline \multirow[t]{7}{*}{6} & 3 students & ○ & police; incidents; because & $\mathrm{D} ; \mathrm{e} ; \circlearrowleft \mho$ (not in IPA) \\
\hline & & I & eradication; device & $\mathrm{e} ;$ ә \\
\hline & & $\mathrm{p}$ & following; & ๑: \\
\hline & & av & house; & ৩ひ \\
\hline & & $\Lambda$ & discovered; & ๑: \\
\hline & & $\partial \mho$ & components; & ๑: \\
\hline & & eI & cable; breaking; investigate & e \\
\hline \multirow[t]{7}{*}{7} & 2 students & ə & $\begin{array}{l}\text { suspected; police; containing; } \\
\text { components; }\end{array}$ & $\begin{array}{l}\Lambda ; \curvearrowright: p ; p \\
\curvearrowright \mho(\text { not in IPA) }\end{array}$ \\
\hline & & av & houses; & $\mathrm{e}$ \\
\hline & & $\mathrm{a}:$ & squad; & $\mathrm{e}$ \\
\hline & & $æ$ & black; bag & $\mathrm{p}$ \\
\hline & & $\Lambda$ & among; others & va or kwa: (not in IPA) \\
\hline & & ๑: & headquarters; & e \\
\hline & & I & explosive; & \\
\hline
\end{tabular}

Table 2. Replacement of L2 English Sounds by L1 Pendalungan Students

\begin{tabular}{|c|c|}
\hline Category & Examples \\
\hline $\begin{array}{l}\text { replaced by another vowel in the } \\
\text { same class of sound }\end{array}$ & $\begin{array}{l}/ \mathrm{e} / \text { for } / \mathrm{I} / \text { as in experience, eradication, explosive } \\
/ \mathrm{J} / \text { for } / \Lambda / \text { as in corruption } \\
/ \mathrm{p} / \text { for } / \mathrm{\partial} / \text { as in police } \\
/ \mathrm{e} / \text { for } / \mathrm{a} / \text { as in incident } \\
/ \Lambda / \text { for } / \mathrm{\partial} / \text { as in suspected } \\
/ \mathrm{p} / \text { for } / \Lambda / \text { as in among; others }\end{array}$ \\
\hline $\begin{array}{l}\text { replaced by another vowel in a } \\
\text { different class of sound (short/ } \\
\text { long vowel by diphthong, and vice } \\
\text { versa) }\end{array}$ & 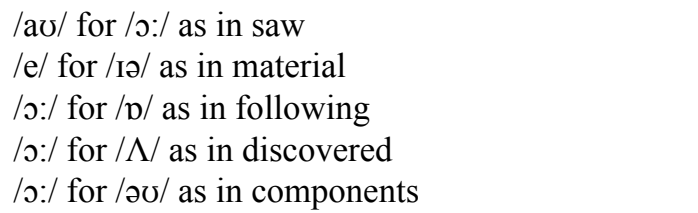 \\
\hline
\end{tabular}


Sound Addition

Since this study focused on the exploration of vowel phonemes, the section of sound addition will describe to the extent of vowel addition only. This study finding of sound addition is limited to 2 cases; /e/ into /eI/ and /ra/ into /re/ (although it may not be acceptable in English standard pronunciation. The two additions occur in said / sed/ becomes /serd/ and experience /Ik'spirions/ becomes / Ik'spiriens/. When looked closer, the words have double vowels. When traced back to the mother languages of Pendalungan, either Madurese or Javanese rarely have double-vowel words; one vowel represents one sound. Unlike English words, two vowels mostly represent one sound. It may explain the phenomenon of adding sound in Pendalungan students.

\section{Sound Omission}

Similar to that of sound addition, sound omission has only two cases. These cases were found by comparing the actual sounds to what the subjects pronounced them. The two cases included omission of /a/ in /aI/ as in pipe, comprising, and assigned and that of $/ \mathrm{I} /$ in $/$ eI/ as in cable, breaking, and investigate. As opposed to the explanation of sound addition, in sound omission the vowels in words are not identical. In the case of omitting /a/ in /aI/, the vowels are single, while in the other case is varied. In the first case, the subjects simply pronounced the vowel alphabet /i/, whereas in the other case they pronounce only the preceding vowel. In the second case, it can be assumed that the Pendalungan students are aware that the letter 'a' or 'e' can be pronounced as /e/, but at the same time, they are not aware that the syllable should be pronounced with a diphthong /eI/, resulting in a phonetic error. However, one that is identical in the two cases, while the vowel phonemes are diphthongs ended in $/ \mathrm{I} /$, none of the words mentioned have double vowels ended with the letter ' $i$ '. Therefore, this little evidence can help us in creating a pattern of sound omission.
The errors made by the Pendalungan students in sound replacement are commonly found as the failure to perceive the ortographic writing with its sound; the vowels are pronounced as they are written. This finding applies in both categories, therefore making it easier to predict upcoming errors in different words. In line with this study finding, Muhyidin (2016) who researched phonological intereference of Indonesian students found nine vowel substitutions but only one that is similar to this finding; $/ \mho /$ substitutes $/ \Lambda /$. This contrast may be explained by different subjects of the study. Whereas Muhyidin (2016) specified his subject by identifying them as Indonesian EFL learners, this study went deeper by specifying the subjects' mother tongue other than Indonesian language. Such difference makes it possible to explain the different findings. Additionally, Saha \& Das Mandal (2014) indicated in their study of L1 Bengali that English vowels have a lot of variations in L1 students as they draw their pronounciation undethrstanding of the L2 by referring to their L1. The same happens in this study, where certain vowel phonemes were substituted by other different vowel phonemes in different words.

Sound replacement is common in L2 learners because as they are developing their language skills, they keep finding words containing sounds which are not familiar to them. Thus, replacing the unfamiliar sounds with those more familiar to them, like taken from their L1, turns out to be their strategy when producing the sound. Although it may not be acceptable for the long run, being aware of sounds which are often replaced by students is important.

Aside from the three types described, the study indicated some mispronunciation of vowels. The mispronounced vowels result in unidentified vowel, such as /re/ and / $/ \mathrm{v} /$. Such mispronunciation can be a result of misplaced stress which is further explained in suprasegmental aspect of phonology. Although it was not tested whether such 
mispronunciation significantly hindered the understandability of the word, it is worth a note for EFL teachers that teaching pronunciation encompasses a vast area of phonology; involving the observable segmental aspect of consonants and vowels to the superimposed in the syllable suprasegmental aspect (Muhyidin, 2016).

The study has explored in depth the phonological interference of Pendalungan language in English as a foreign language. However, none of the findings stated clearly whether Javanese language dominates the errors made by Pendalungan students. Wardani \& Suwartono (2019) have identified vowels which are problems for Javanese students /æ,

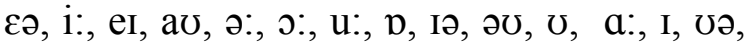
गI, aI/, while the study by Muhassin, et al. (2018) on Madurese students specified the vowels of $/ \mathrm{\partial} /$ and $/ \mathrm{I} /$. As the study on Javanese students present more vowels than that of the Madurese, it seems unfair to say that errors in Javanese language dominates the interference. Moreover, the difference in research method and instrument for data collection from both studies may hinder the comparison.

\section{Conclusion}

The present study has explored some phonological interference of pronouncing vowels in Pendalungan students. It was found that students tend to replace vowels and rarely add or omit them. The findings are related to the nature of both L1s, in which students have mistakenly pronounced words as they are written. In the cases of sound replacement, it was found that replacement occured in two different categories; a) replaced by vowel in the same class, and b) replaced by vowel in a different class. However, this study is limited to the phonological interferences encountered from EFL reading, which comprises not only vowels or segmental aspect of phonology but also suprasegmental one, including word and sentence stresses and intonation, whereas only vowel is analyzed. Therefore, it is suggested that prospective studies add more focuses on the studies in order to obtain a more comprehensive finding.

\section{References}

Ambalegin, \& Suryani, M. S. (2018). Mother Tongue Affecting the English Vowel Pronounciation of Batak Toba Adults. In AICLL The 1st Annual International Conference on Language and Literature (66-80). Medan: KnE Social Sciences \& Humanities. https://doi.org/10.18502/ kss.v3i4.1920

Ambalegin, A., \& Hulu, F. (2019). EFL Learners' Phonological Interference of English Articulation. Jurnal Basis, 6(2), 145-154. doi:10.33884/basisupb.v6i2.1415

Aulia, V. (2018). Identifying the Problem of Banjarese Speaking Students in Learning English Pronunciation. Journal of English Language Studies, 3(1). 1-17

Cardoso, W. (2007). The variable development of English word-final stops by Brazilian. Change, 19, 1-30

Crystal, D. (2003). English as a Global Language. Cambridge: Cambridge University Press.

Dulay, H., Burt, M.K., \& Krashen, S. (1982). Language Two. New York, NY: Oxford University Press

Ellis, R. (1997). Second Language Acquisition. Oxford: Oxford University Press.

Harwan, R. (2019). Bahasa Daerah di Pulau Jawa Ada 10 Dari 668 Bahasa [Vernaculars in Java Island, 10 out of 668]. https://bahasawan.id/t/bahasadaerah-di-pulau-jawa-ada-10-dari-668bahasa/499 (Retrieved on May 21, 2020).

Flege, J. E. (1995). Second language speech learning: Theory, findings, and problems. In W. Strange (Ed.), Speech perception and linguistic experience: Issues in cross-linguistic research (pp. 233-277). Timonium, MD: York Press. 
Muhassin, M., Ansar, F.A., Putri, P.P. (2018). Phonological Interference of Madurese Towards English at the Eleventh Students of SMA Al Hikam Bangkalan East Java. English Education: Jurnal Tadris Bahasa Inggris, 11(2), 144-159.

Muhyidin, M. (2016). Phonological Interference in the English Pronunciation. Universum, 10(2). 209-217

Raharjo, C.P.(2006). Pendalungan: Sebuah 'Periuk Besar' Masyarakat Multikultural'. Paper presented at Jelajah Budaya, Balai Kajian Sejarah dan Nilai Tradisional Yogyakarta.

Saha, S.N. \& Das Mandal, S. K. (2014). Phonetic and phonological interference of English pronunciation by native Bengali (L1Bengali,L2-English) speakers. Paper presented at the 17th Oriental Chapter of the International Committee for the Coordination and Standardization of Speech Databases and Assessment Techniques (COCOSDA), Phuket, 2014. 1-6, doi: 10.1109/ICSDA.2014.7051429.

Wardani, N.A. \& Suwartono, T. (2019). Javanese Language Interference in the Pronunciation of English Phonemes. Celtic: A Journal of Culture, English Language Teaching, Literature, \& Linguistics, 6(2). 14-25

Weinreich, U. (1953). Languages in Contact: Findings and Problems. New Yor, NY: Linguistic Circle of New York

Wells. J.C. (2000). Overcoming phonetic interference. English Phonetics, Journal of the English Phonetic Society of Japan, 3. 9-21

Zoebazary, M.I. (2017). Orang Pendalungan: Penganyam Kebudayaan di Tapal Kuda. Jember: Paguyuban Pendhalungan Jember. 